Article

\title{
Factor Decomposition of the Changes in the Rural Regional Income Inequality in Southwestern Mountainous Area of China
}

\author{
Yun $X u^{*}$, Xiaoping Qiu ${ }^{(\mathbb{D}}$, Xueting Yang ${ }^{(\mathbb{D})}$ and Guojie Chen \\ Institute of Mountain Hazards and Environment, Chinese Academy of Sciences, Chengdu 610041, China; \\ qiu_xiaoping@foxmail.com (X.Q.); cheerxueting@126.com (X.Y.); chengj@imde.ac.cn (G.C.) \\ * Correspondence: xuyun@imde.ac.cn
}

Received: 1 August 2018; Accepted: 3 September 2018; Published: 5 September 2018

\begin{abstract}
This study aimed to determine factors of rural income inequality changes in Aba Tibetan and Qiang Autonomous Prefecture, Sichuan, China, to help formulate measures to reduce regional inequality and alleviate poverty in the southwestern mountainous area of China, which experiences frequent natural disasters and poor living conditions. Changes in rural income inequality are examined, which are then decomposed into different component factors based on the Gini index. Income inequality is comprised of four types of income source: wages, household operations, properties, and transfers. This analysis focuses on the period of 2003 to 2011-a special transitional stage during which the Wenchuan earthquake intervened. The results indicate that income from household operations plays a dominant role in income inequality. Its contribution to the overall inequality fluctuates from $36.40 \%$ to $50.39 \%$ and had a positive effect on reducing inequality after the earthquake. Wage income contributed the second-most to income inequality and had positive and negative effects on reducing inequality before and after the earthquake, respectively. Transfer and property incomes are important forces in income inequality that have different influencing mechanisms. Transfer income positively helps reduce income inequality. Exclusive favors or preferences should be granted to such areas.
\end{abstract}

Keywords: regional inequality reduction; poverty alleviation; household operations; major function oriented zoning (MFOZ) planning; Aba Tibetan and Qiang Autonomous Prefecture

\section{Introduction}

The average income of rural inhabitants is an important indicator of the level of economic development in rural areas [1]. It also provides an important reference scale of economic welfare for farmers [2]. Income distribution is consistently one of the major focuses of economic research. According to the United Nation's (UN's) Human Development Report and the World Bank's World Development Indicators, income distribution indicators such as per capita income, income inequality, and poverty are important indices of human socio-economic development. For most developing countries in the world, prevalent rural income inequality has attracted the attention of the international community-from governmental agencies to scientists and the public-and has been brought under increased scrutiny as a potential brake on economic growth [3,4].

Most previous studies on rural inequality focused on the following aspects. First, some theoretical studies examined rural income inequality, including dual economic theory [5], the vicious cycle of poverty [6], theory of population flow [7], agricultural investment theory [8,9], and the agricultural green revolution [10]. These studies discerned clear relationships between income inequality and economic development, and supplied the ideas for introducing the principles and policy orientations 
of realizing balanced development. Second, empirical studies reported the characteristics of rural income inequality in recent decades. Since rural income inequality is complex, these studies focused on overall regional inequality, and inter- and intra-regional inequality, to explore the space structures [11], trends in changes [12-15], and driving forces. Third, analyses of factors of income inequality and policy suggestions have been produced. Related literature revealed rural inequality influencing factors from diverse perspectives, such as agricultural trade liberalization [16], health levels [17], migration of labor force from rural areas [18,19], household socio-economic characteristics [20], livelihood assets [21], public policy [22,23], and income sources [24-26], with an emphasis on non-farming and farming income particularly $[23,27,28]$, even on forestry-based income [29], environmental income [30,31], and transfers [32]. Using the Gini index decomposition analysis to study the impact of income sources on income inequality is a research hotspot, in particular non-farming income sources. However, inconsistent results have been reported. For example, some studies found that non-farming income played a role in enlarging rural inequality [33-35], whereas others indicated that the opposite is true [36-39]. Some of the differences in outcome may be due to differences in the type of rural household data, the definition of what consists of rural activities, and the particular method of decomposing income inequality $[25,40]$. Such differences can be further attributed to differences in the time dimension, stage of rural economic development, and access to rural assets $[27,28,41]$. Moreover, whereas rural economic development and the diversification of rural household income structure need to be clarified, the role of each type of rural income in generating or decreasing household income inequality needs to be ascertained, and the diversity of policy measures should closely match the diversity of the rural economy for which location-specific policies are necessary.

Since the early 1990s, income differences of rural residents in China began to attract the attention of the Chinese government and researchers. Three rural issues-agriculture, rural areas, and farmers-have been increasingly important for China's socio-economic development and poverty elimination in rural areas. Income inequality of rural inhabitants is extensive, encompassing the inequality between the hinterland and southeast coastal regions, and among and within the different provinces or regions. Different methodologies, measurement indices, data sources, data processing modes, spatial and temporal scales, and time periods have been utilized to explore this inequality. Some common characteristics of rural inequality have been confirmed, whereas other research results have been controversial [42-44]. In the influencing factor analysis of rural income inequality, factor decomposition and regression correlation analysis are mainly employed [45-47]. China's rural regional inequality is attributed to factors such as income structure [48-50], disparity composition [42,51,52], livelihood capital [53-57], geographical factors [1,58], and institutions and policies [59-62]. For income structure, wage income or nonfarm income is dominant in the increase in the rural regional gap, so farm-related income is helpful for narrowing the gap. The growth in intra-province disparity is mainly derived from the wage gap of non-farm income, whereas rural township enterprises account for $40-50 \%$ of rural inequality between the east and west. Other non-farm incomes also play a key role in increasing the rural disparity [48-50]. However, farm-related income is thought to play an important role in rural inequality [9] and even serve as the main factor of narrowing the gap [17]. The different views expressed in related studies are not only attributed to different methodologies, index, data sources, spatial and temporal scales, and time periods, but also to their focus on the total change rather than the factor decomposition in changes of rural income inequality. Liu studied the impact of income sources on rural income inequality in China by improving the Gini index decomposition analysis, given the merits of the decomposable Gini coefficient [63]. By applying decomposition analysis, changes in rural income inequality were decomposed into different income factor changes. The different income factors were placed under further structural decomposition to identify the roles of the factors and the mechanisms by which they work. At present, Liu's results have been commonly used in related studies on large-scale areas in China [64-67]. Nevertheless, such studies for certain areas are scarce, especially in ethnic minority areas, mountainous areas, and poverty-stricken areas. The southwestern mountainous area of China is an area that has all three characteristics. It is 
an underdeveloped area with a vast territory and frequent natural disasters. It is necessary to clarify the relationship between income factors and rural inequality in the area, under the constraints of natural disasters and the fragile ecological environment. In addition, China has implemented the major function oriented zoning (MFOZ) strategy in recent years, thus industrial development and urbanization of the southwestern mountainous area is under restriction due to its extremely important ecological function. Hence, it is urgent to study and reduce regional income inequality in both this and similar areas.

In this paper, the Aba Tibetan and Qiang Autonomous Prefecture (Aba) was chosen as the study area. Rural income inequality and factor decomposition of Aba were studied against the background of the transition to the prohibited and restricted development zones. The aim of this study was to (1) clarify features of income structure change in ethnic minority areas, poverty-stricken areas, and mountainous areas; (2) decompose income inequality and explain the effect of income factors on rural income inequality; and (3) identify policy implications for rural inequality reduction of prohibited development zones and restricted development zones.

\section{Materials and Methods}

\subsection{Study Area}

Aba is situated in Southwest China $\left(30^{\circ} 35^{\prime}-34^{\circ} 19^{\prime} \mathrm{N}, 100^{\circ} 30^{\prime}-104^{\circ} 27^{\prime} \mathrm{E}\right)$, with a population of 0.9 million. Aba covers a total area of $8.3 \times 10^{4} \mathrm{~km}^{2}$ and includes 13 counties, including Wenchuan, Lixian, Maoxian, Songpan, Jiuzhaigou, Jinchuan, Xiaojin, Heishui, Maerkang, Rangtang, Aba, Ruoergai, and Hongyuan (Figure 1). It belongs to the southeast margin of the Qinghai-Tibet plateau and is characterized by complicated landforms, diverse climate types, and an abundance of natural resources. Consequently, hydroelectric energy, eco-agriculture, and eco-tourism serve as the pillar industries for economic development in Aba. Aba is also an area for ethnic minorities. It is the second Tibetan region in Sichuan province and the northernmost Qiang-inhabited area in China. Aba is an unadvanced area and its per capita farmer annual income is $76.09 \%$ and $66.83 \%$ of the average levels of rural inhabitants in Sichuan Province and China, respectively. It is a special area with a fragile environment and frequent natural disasters. The area experienced the Wenchuan earthquake in 2008. However, its regional ecological function is extremely important. According to MFOZ planning in China, Aba should be transformed into prohibited and restricted development zones oriented to ecological construction, and is divided into ecological safety zones and cultural and natural heritage zones in the spatial planning system. Due to the slow rural economic development featured by lower rural income and its regional ecological function, Aba has become a suitable experimental site for identifying the driving forces of rural regional income inequality from the perspective of income structure variation, and for clarifying policy proposals to shrink inequality in such areas with the implementation of the MFOZ strategy.

\subsection{Methods}

\subsubsection{Data Sources}

The essential features of rural inequality in Aba have been explored over a longer sample period (1978-2011), whereas income inequality has been explored in a relatively shorter sample periods (2003-2011) due to the lack of consistent data. The data of per capita GDP were used to characterize rural inequality because this is the only data source covering a reasonably long period of time, 1978-2011. As for inequality decomposition by factor components, the data of rural incomes by sources are available on a per capita basis via annual sample surveys since 2003. The major sources of data for this paper were the Aba Bureau of Statistics, Sichuan Provincial Bureau of Statistics, and China's National Bureau of Statistics [63,64]. 


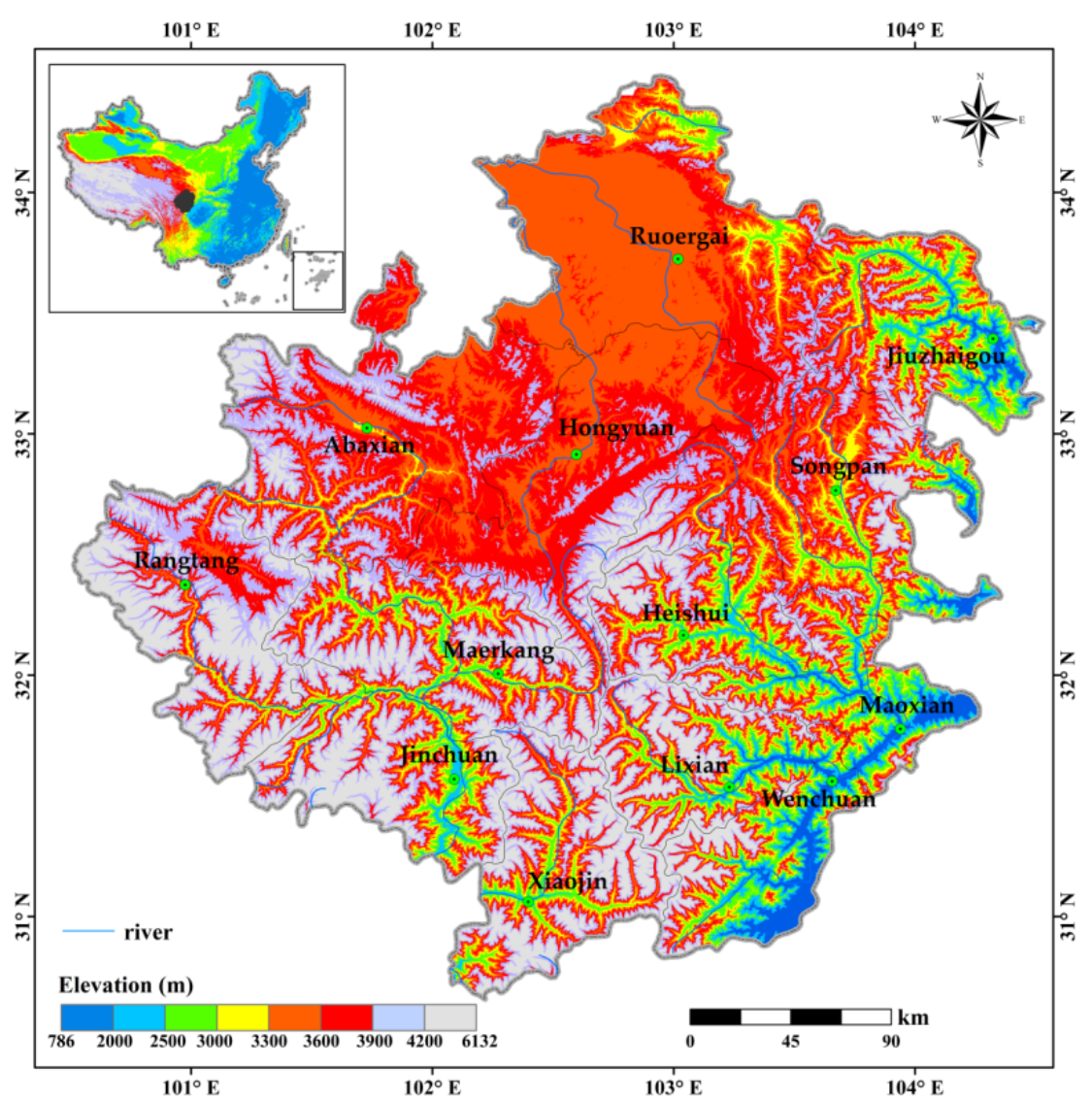

Figure 1. Location of study area in China.

\subsubsection{Measuring Method of Rural Regional Income Inequality}

The Gini coefficient was applied to examine the income equality over time at the prefecture-level in Aba, taking per capita GDP as an index. The equation is [68]

$$
G=\left[\sum_{i=1}^{\mathrm{n}} \sum_{j=1}^{\mathrm{n}}\left|y_{j}-y_{i}\right| p_{i} p_{j}\right] / 2 u
$$

where in a given region, $G$ is the Gini coefficient, $y_{i}(i=1,2,3, \ldots, n)$ corresponds to per capita GDP of the $i$ th subregion, $u$ is per capita GDP of the region as a whole, $\mathrm{n}$ is the number of subregions, and $p_{i}$ and $p_{j}$ represent the proportion of population of the $i$ th and $j$ th subregions in the total population, respectively.

\subsubsection{Decomposing Method of Rural Regional Income Inequality}

In this study, inequality decomposition by factor components is based on Shorrocks' Gini coefficient method and Liu's research [63,69]. Liu's factor decomposition method is a further improvement and expansion of the Gini coefficient decomposition method proposed by Shorrocks, which analyzes the contribution of different income factors on income inequality, and explores the impact of changes in the concentration and structure of the different factors themselves on the changes in contribution of income inequality.

This decomposition method was chosen in this study for reasons as follows: (1) it is necessary to measure the size of income inequality as well as to analyze changes in income inequality. Although the contribution of different income factors to income inequality is important, changes in the contribution of different income factors to income inequality are more important. The absolute contribution of a 
factor to income inequality may be small, but the factor may be an important one that leads to changes in income inequality. It is of greater significance to analyze changes in the contribution of different factors than to study their contribution to changes in income inequality; (2) This factor decomposition method can be applied to decompose the overall rural income inequality into individual contributions by different income sources-wages, household operations, properties, and transfers-and can reflect changes in actual income levels brought about by the government through taxation redistribution, fiscal transfers, subsidies, and so on. The method helps avoid as many loopholes as possible implicated by single factor analysis methods; (3) The method of factor decomposition by income sources enables the use of relatively long-time sequences of rural net per capita income data in statistical yearbooks published by the governments, by which the reliability and accuracy of the results are guaranteed. The method provides the possibility of comparative analysis of rural income inequality in different regions in China.

The decomposition process can be divided into the following steps: Step 1 involves decomposing the income inequality into different income factors to explore the contribution of income factors to income inequality. Step 2 further decomposes the factor contribution to changes in Gini ratio into different ingredients to analyze how each income factor acts on income inequality. When the influence of each factor on inequality changes is decomposed into its structural effects and its concentration effects, the influence mechanism of the income factors on income inequality and policy suggestions are elucidated. Inequality decomposition by factor components is helpful for policymakers to determine the source of income inequality and formulate rural development policy in these special areas similar to Aba.

Step 1 includes two key links. First, decomposition of the total income inequality by income sources. The overall rural income inequality is decomposed into contributions of different income sources: wages, household operations, properties, and transfers. The equation is given as

$$
G_{A}=\left(u_{1} / u\right) G_{1}^{*}+\ldots+\left(u_{k} / u\right) G_{k}^{*}
$$

where $G_{A}$ is the total Gini coefficient of the region, $k$ is the $k$ th income factor (income source), $u$ is the average value of income as a whole, $u_{k}$ is the average value of the $k$ th income factor, and $G_{k}{ }^{*}$ represents the virtual Gini coefficient of the $k$ th income factor.

$G_{k}{ }^{*}$ is not usually what is meant by 'Gini coefficient', and is obtained not by directly calculating the Gini coefficient of the kth income factor, but by counting on the basis of the sorting feature of the total income and the $k$ th factor's income, that is, when $y_{1} \leq y_{2} \leq \ldots \leq y_{\mathrm{n}}$. The expression is

$$
G_{k}^{*}=2 \operatorname{cov}\left(y_{k}, F(y)\right) / u_{k}
$$

where $\operatorname{cov}\left(y_{k}, F(y)\right)$ is the covariance of the $i$ th factor's income and the total income, and $u_{k}$ is the average value of the $k$ th income factor.

Second, decompose the contribution of the income factors to income inequality. According to Equation (2), the overall rural income inequality is composed of contributions of the $k$ th income factor. The contribution of the $k$ th income factor $S_{k}$ is

$$
S_{k}=\left(u_{k} / u\right) \times\left(G_{k}^{*} / G_{A}\right)
$$

where $u_{k} / u$ denotes the share ratio of the value of the $k$ th income factor to average value of income, and $G_{k}{ }^{*} / G_{A}$ refers to the relative concentration ratio between virtual Gini coefficient of the $k$ th income factor and the total Gini coefficient.

Step 2 focuses on the analytic expression of the influence of each factor on inequality change. Decompose the factor contribution to changes in the Gini ratio. Factor contribution is decomposed into different ingredients, including structural effects, concentration effects, and comprehensive effects. 
Based on Equation (3), contribution change of the $k$ th income factor in a certain time interval is expressed as

$$
\begin{gathered}
\Delta S_{k}=S_{t+1}-S_{t}=u_{k(t+1)}^{\prime} \times G^{\prime}{ }_{k(t+1)}-u_{k t}^{\prime} \times G_{k t}^{\prime} \\
=\Delta G_{k}^{\prime} \times u_{k t}^{\prime}+\Delta u_{k}^{\prime} \times G_{k t}^{\prime}+\Delta G^{\prime}{ }_{k} \times \Delta u_{k}^{\prime}
\end{gathered}
$$

where $\Delta S_{k}$ refers to the contribution change of the $k$ th income factor between the time of $t$ and $t+1$, $u_{k}^{\prime}$ represents the weight of the $k$ th income factor in total income, and $G^{\prime}{ }_{k}$ is the weight of virtual Gini coefficient of the $k$ th income factor in total Gini coefficient.

That is, the contribution of the $k$ th income factor to the overall income inequality can be decomposed into three parts: (1) $\Delta G^{\prime}{ }_{k} \times u^{\prime}{ }_{k t}$ denotes the concentration effect, which is induced by concentration changes in the $k$ th income factor; (2) $\Delta u_{k}^{\prime} \times G^{\prime}{ }_{k t}$ represents the structural effect, which is produced by proportion changes in the $k$ th income factor; and (3) $\Delta G^{\prime}{ }_{k} \times \Delta u^{\prime}{ }_{k}$ stands for the comprehensive effect, which is produced by the combined effect of both the weight and concentration of the $k$ th income factor.

\section{Results}

\subsection{Characteristics of Rural Income Inequality}

The Gini coefficient $(G)$ of per capita farmer annual net income of Aba gradually increased from 1978 to 2011, except in 2008 when the Wenchuan earthquake occurred. During the period of 1978-2000, significant economic growth occurred due to the exploitation of hydraulic power, extraction of mineral resources, and the development of high energy consumption industries. Then, $\mathrm{G}$ entered a stagnant phase in 2000-2008, during which the development of the western region in China was implemented. An increasing number of preferential policies were introduced to reduce regional inequality, such as returning cropland to forestry and grass, financial transfer and allotment, special poverty relief policy for poverty-stricken areas and ethnic minority areas. There was a turning point in 2008 due to disaster relief and related funds supplied by governments and agencies at home and abroad. Since then, G has increased during 2009 to 2011 again, owing to a gradual decrease in special transfer payments, counterpart assistance, and donations to the Wenchuan earthquake reconstruction (Figure 2).

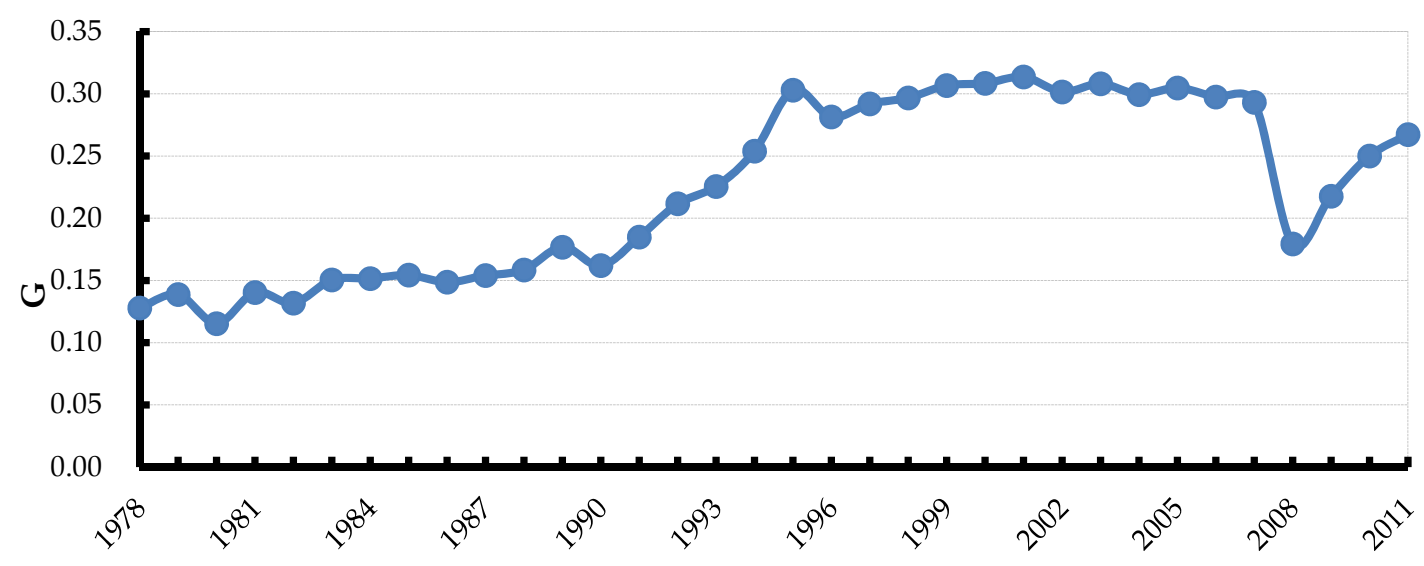

Figure 2. Changes in rural per capital annual net income Gini coefficient (G) in Aba (1978-2011).

\subsection{Composition Changes in per Capita Annual Net Income}

Based on the statistics, the per capita farmer annual net income of rural households during the period of 2003-2011 in Aba was composed of wage income, property income, transfer income, and net income from household operations (Table 1). Wage income accounted for 19.79 to $24.95 \%$ of the total income during 2003-2007, but this proportion increased from $17.98 \%$ in 2008 to $30.09 \%$ in 2011 after the Wenchuan earthquake. Contribution of household operations to the total income was the greatest, ranging from $61.75 \%$ to $67.62 \%$ in the period of 2003 to 2007, then increased from 2008 
to 2011. Property income accounted for the smallest percentage of the total income among the four income factors, showing a decreasing trend when it dropped from $6.33 \%$ in 2003 down to $0.25 \%$ in 2011. Changes in transfer income were still obvious before and after the earthquake, whereas the fluctuation in transfer income was relatively steady before 2008, ranging from 6.40 to $10.05 \%$, reaching a high point in 2008, and beginning to decline after that. Therefore, income from household operations and wage play an important role in rural income and accounts for a large share of farmers' wealth. The proportion of transfer income in total income considerably exceeds pre-disaster levels in the post-disaster period, although it suffered a decline after 2008. Nevertheless, contribution of property to total income is still on the decline after the earthquake.

Table 1. Composition of per capita annual net income of rural households and percentage contribution to the Gini ratio by its factor income in Aba (2003-2011).

\begin{tabular}{|c|c|c|c|c|c|c|c|c|}
\hline \multirow[t]{2}{*}{ Year } & \multicolumn{4}{|c|}{$\begin{array}{c}\text { Composition of per Capita Annual Net Income of Rural } \\
\text { Household (\%) }\end{array}$} & \multicolumn{4}{|c|}{$\begin{array}{l}\text { Percentage Contribution to the Gini Ratio by Factor } \\
\text { Income (\%) }\end{array}$} \\
\hline & Wage & Household Operations & Property & Transfer & Wage & Household Operations & Property & Transfer \\
\hline 2003 & 20.18 & 67.09 & 6.33 & 6.40 & 27.96 & 50.39 & 12.15 & 9.50 \\
\hline 2004 & 24.95 & 63.55 & 5.21 & 6.29 & 28.69 & 36.40 & 6.22 & 28.69 \\
\hline 2005 & 19.79 & 67.62 & 3.71 & 8.87 & 31.44 & 46.41 & 10.33 & 11.83 \\
\hline 2006 & 22.81 & 62.05 & 5.09 & 10.05 & 31.53 & 39.41 & 17.56 & 11.50 \\
\hline 2007 & 23.25 & 61.75 & 5.25 & 9.74 & 32.02 & 39.98 & 15.14 & 12.86 \\
\hline 2008 & 17.98 & 40.59 & 2.64 & 38.79 & 13.03 & 48.38 & 3.28 & 35.31 \\
\hline 2009 & 21.79 & 42.79 & 1.87 & 33.55 & 19.22 & 47.24 & 3.47 & 30.07 \\
\hline 2010 & 26.11 & 53.04 & 2.57 & 18.28 & 29.21 & 45.42 & 6.03 & 19.34 \\
\hline 2011 & 30.09 & 54.33 & 0.25 & 15.33 & 34.79 & 46.06 & 4.29 & 14.86 \\
\hline
\end{tabular}

\subsection{Factor Decomposition of Rural Income Inequality}

The contribution of wage income to income equality ranged from 13.03 to $34.79 \%$ with a trough in 2008 due to the Wenchuan earthquake, but a dramatic increase appeared during the post-disaster reconstruction. Household operation contribution to income equality reached 36.40 to $50.39 \%$ before the earthquake, then held at more than $45 \%$ and was stable after that. This implies that income from household operations plays the most important role in Aba's rural regional income inequality, followed by wage income. Transfer income has a strong effect on income inequality, as its contribution percentage varied from 9.50 to $35.31 \%$, and reached a peak at $35.31 \%$ in 2008 . The contribution percentage of property income fluctuated downward, ranging from $12.15 \%$ in 2003 to $4.29 \%$ in 2011 , with the lowest value in 2008. Before the earthquake, its contribution to income inequality was greater than that of transfer income. Its contribution was affected by the earthquake and recovered sluggishly thereafter. In contrast with other income factors, it was the least important in the period following the earthquake (Table 1).

Wage income had a significant positive contribution to narrowing income inequality before the earthquake, and in contrast, induced an increase in income inequality with the concentration increase effect and the share increase effect after the earthquake. Income from household operations resulted in a decrease in income inequality as the concentration decrease effect was greater than the share increase effect after the earthquake. Yet, its role in declining income inequality before the earthquake is uncertain. Property income and transfer income have different influencing mechanisms in affecting rural income inequality. The contribution from property income was mainly due to changes in its share effect. It had a positive effect on reducing income inequality after the earthquake. The conflict between the concentration effect and the share effect was not distinct, except in 2010 to 2011, and the peak value of total contribution of the concentration and share effects in 2010 to 2011 was related to the completion of reconstruction scheduled in 2011. The contribution from transfer income was mainly due to changes in its share and concentration effects. In Aba, transfer income played a positive role in decreasing income inequality, and its positive effect reached a peak in 2007 to 2008 (Table 1, Figure 3). 


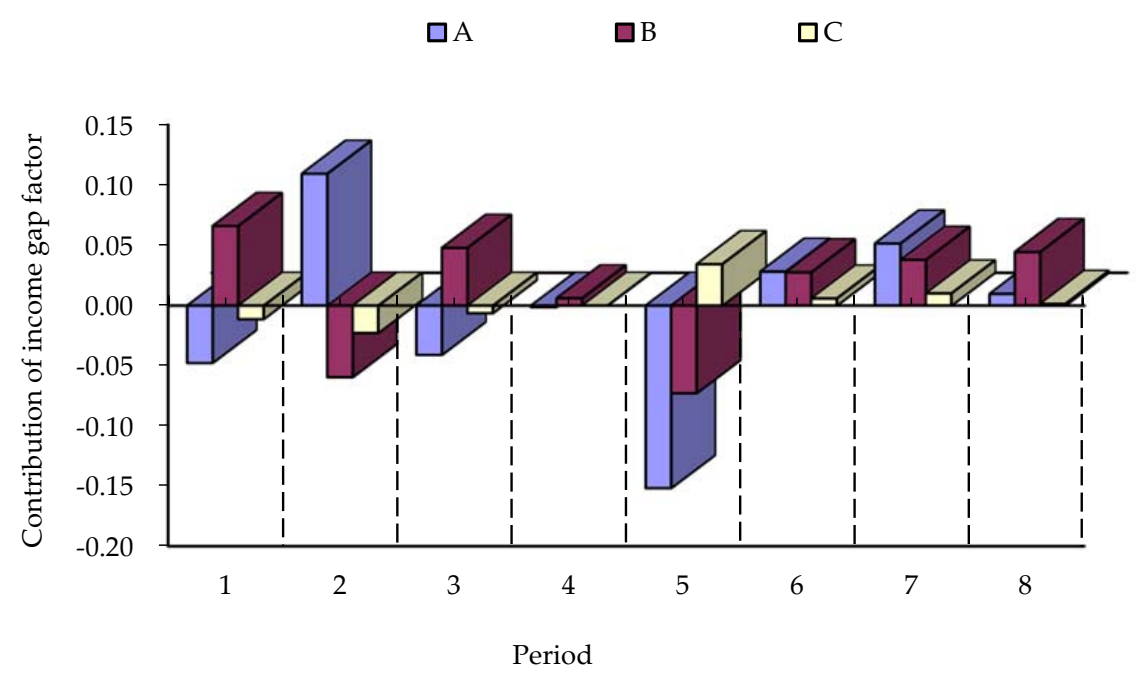

(a)

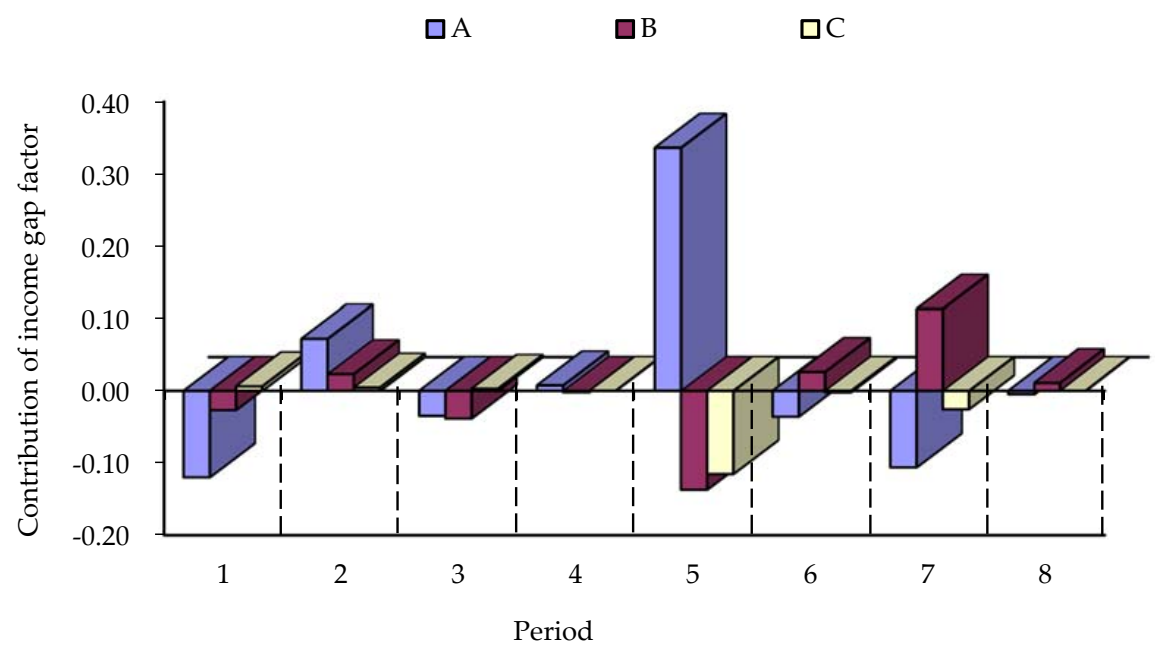

(b)

$\square \mathrm{A} \quad \square \mathrm{B} \quad \square \mathrm{C}$

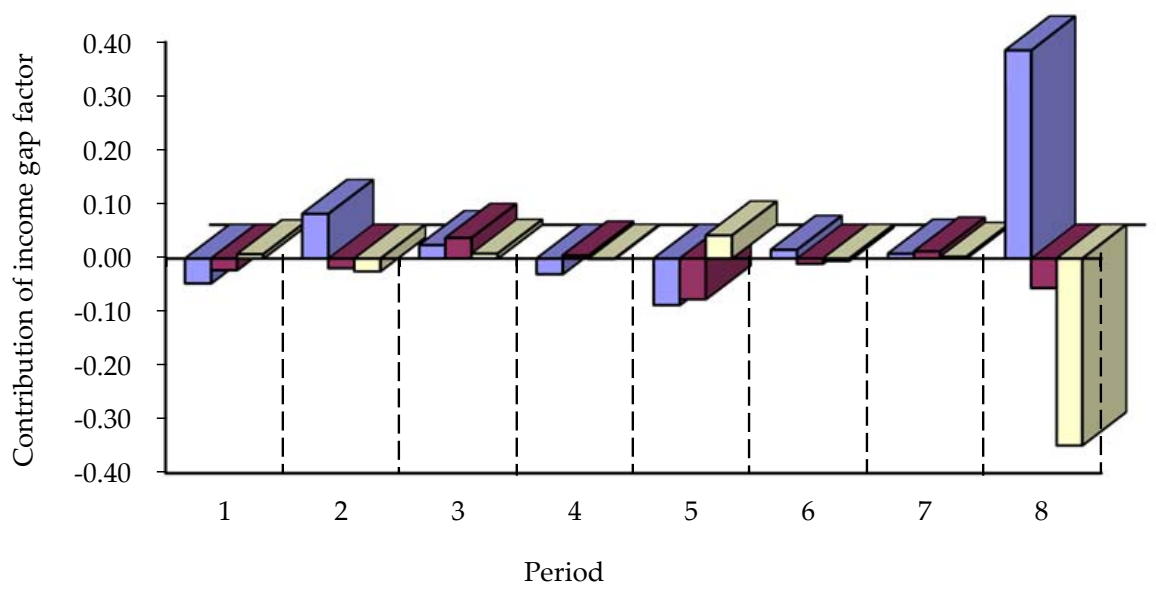

(c)

Figure 3. Cont. 


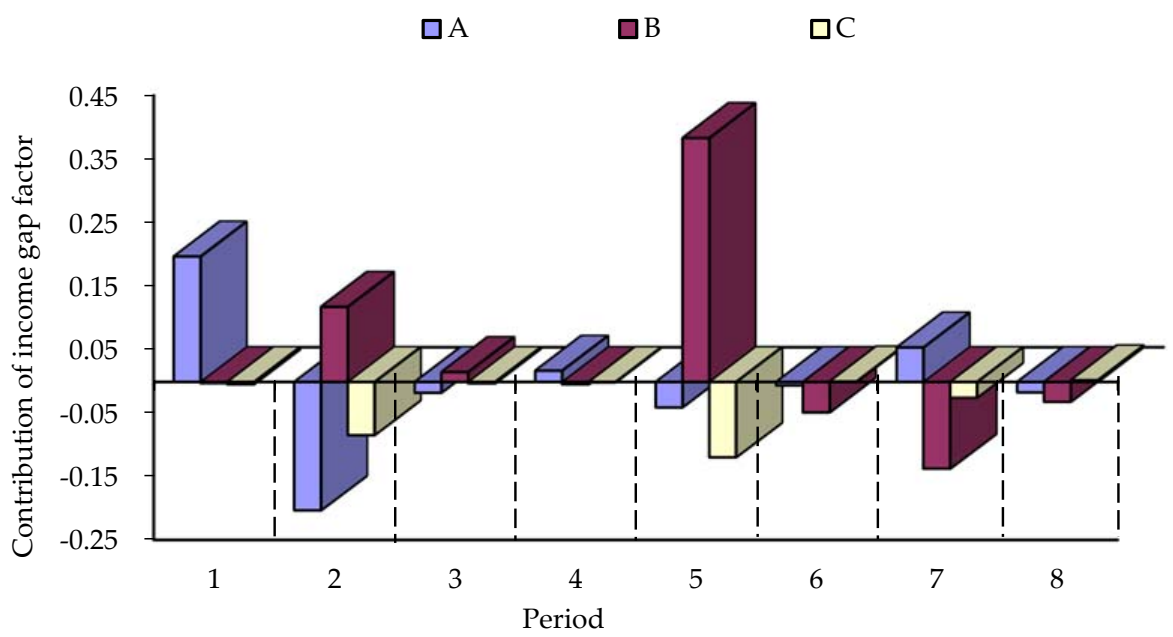

(d)

Figure 3. Decomposing of factor contribution to changes in Gini ratio in of Aba (2003-2011). Structure changes in (a) rural wages' contribution; (b) rural household operations' contribution; (c) rural properties' contribution; and (d) rural transfers' contribution. Note: A denotes contribution of income factor concentration ratio changes, B denotes contribution of income factor proportion changes, and C denotes total contribution. Periods 1, 2, 3, 4, 5, 6, 7, and 8 denote 2003-2004, 2004-2005, 2005-2006, 2006-2007, 2007-2008, 2008-2009, 2009-2010, and 2010-2011, respectively.

\section{Discussion}

This study examined the effects of rural income from different sources on rural income inequality in a minority area in the southwestern mountainous area of China-a developing and transitioning area-using a conventional method of inequality decomposition by income sources, the Gini index. The method was proposed and exemplified by Liu [63] for rural China. Then, similar studies in the given area in rural China around the same time were conducted by Tang in Hunan Province [65], He in minority areas of China [66], Wu in Jiangsu Province [64], and Sun (2011) in Shandong Province [67]. Notably, Davis painted a clear picture of multiple activities across rural space and diversification across rural households in a number of developing and transitioning countries by the decomposition of inequality by factor components, through the application of the Gini index, with an emphasis on the comparability of results, which permitted cross-country comparisons at developing and transitioning stages of rural economic development [25].

In fact, although there are wide range of studies on rural income inequality decomposition using diverse methods, it is hard to compare results among similar studies in different countries since definitions and methods are tailored for a given country and area [25]. Moreover, since different decomposition rules provide different results simply because they measure different things, there is no meaning in deriving conclusions from these results, let alone using diverse methods [70]. Therefore, several nuanced points of focus emerge when we consider interior relationships of income factors with the data decomposed by income sources. First, definitions and classification of the rural household income by income sources in our sample were derived from the National Bureau of Statistics of China, with available data from official statistical yearbooks, which is different from the situation in other studies such as Davis [25] and He [66]. Second, the reliance of ethnic minorities-such as Tibetan and Qiang nationalities—on subsistence agriculture is much higher compared with the Han nationality in the southwestern mountainous area of China. Thus, rural ethnic surplus labor is inclined to work as casual labor around their own counties rather than shift to large central cities and developed areas on the coast as permanent employees for cash income, due to dissimilarity in values and beliefs and weaknesses in basic cultural and technical qualities. It is implied that it is not the high proportions of high-income households but higher absolute incomes that lift households above the poverty line [31]. 
In order to reduce income inequality, establishment of a minimum income level for the farmer worker should be considered by policy makers. Third, the studied area is typically representative of ethnic minority areas in the southwestern mountainous areas of China, and it is a developing area undergoing a transitional phase facing conflict between improvement of people's livelihood and the protection of the originally fragile environment, further worsened by earthquakes as well as other natural disasters, with a large poverty-stricken and minority population, functioning as a state-level ecological construction-prohibited and restricted development zone. Therefore, its rural income structure varies, and shows a trend of increasing reliance on household operations and transfers at present and for some time in the future. Fourth, in a region such as Aba, natural disasters occur frequently, and changes in rural income structure, as well as the effects of income factors on rural income inequality under the influence of major natural disasters such as Wenchuan earthquake, were observed through case studies. As a result of the aforementioned situation, rural household livelihood strategies and policies in this case are inconsistent with other relevant studies.

Our case study provides a number of insights into determining factors in the task of shrinking the rural income gap in the minority area. In general, we found support for the increasing rural income inequality from the mid of 1990s till the end of 2000s [63-65], whereas wage income played a crucial role in affecting rural income inequality. Nonagricultural wage income is an equalizing income source $[63,70]$. The increased influence of wage income is a direct result of industrialization and urbanization in China $[64,65]$. Household operations are still the dominant source of rural income. Income from household operations has had positive effects on the reduction of the total regional inequality in recent years [63-65]. However, transfer income has increased quickly and steadily [63]. Transfer income influence on rural income inequality is increasing, and it is an equalizing income source through policy adjustments [63].

We did not find support for the claim that wage income has gained the dominant position by taking place of household operations in minority areas [66], and the claim that non-farm income induces greater income inequality in rural areas [25,66]. In terms of the order of contribution to income inequality of the four sources of income, the situation in Aba is somewhat different from that of the nation in general and that in Hunan, and identical to that in Shandong, exhibiting the greatest difference when compared with that in Jiangsu. Our study found that income from household operations plays the most important role in Aba's rural regional income inequality, followed by wage income, transfer income, and property income. Liu's study on rural income inequality in China showed that wage income ranks first, followed by income from household operations, transfer income, and property income, which is the same order in the first two places as in Tang's study on rural income inequality in Hunan. Sun's study on rural income inequality in Shandong agrees with ours. Wu's study on rural income inequality in Jiangsu renders the order of contribution to income inequality from large to small as wage income, property income, transfer income, and income from household operations. The causes of these differences in the results have been delineated in the discussion preceding the presentation of the results of these authors.

In addition, in order to achieve the goals of sustainable regional development and policy optimization in minority areas, continuous research is needed to further validate the results through long-term serial data. Studies from diverse perspectives of cultural change, production mode change, and individual adaptive capacity should be carried out in the future.

According to the discussion above, the results of the study are of reference value in rural and mountainous areas similar to Aba, where the economy is developing, natural conditions are poor, and ethnic minorities are concentrated.

\section{Conclusions and Implications for Rural Income Inequality Reduction}

Wage income plays an important role in Aba's rural regional income inequality, and its contribution to income inequality ranges from $19.22 \%$ to $34.79 \%$-with the exception of only 2008 - second only to income from household operations. The influence of wage income on rural 
inequality increased both before and after the earthquake. Wage income had a positive effect on reducing overall income inequality before the Wenchuan earthquake, yet produced the opposite effect after the earthquake. The positive contribution of wage income to reducing regional inequality mainly came from the share increase effect and the concentration decrease effect before the earthquake, whereas the negative contribution of wage income mainly occurred due to the share increase effect and concentration increase effect after the earthquake, which are a direct consequence of industrialization and urbanization in post-disaster reconstruction. In the context of the creation of prohibited and restricted zones, large-scale and high-strength industrialization and urbanization are under the control of relevant policies. In order to decrease the concentration effect and achieve the goals of income inequality reduction, one of the most important approaches would be, first of all, to promote moderate urbanization and industrialization under the ecological environment construction-oriented policy guidance. It is key to cultivate more wage income sources consistent with the functional orientation by adjusting regional industrial structure and developing low-carbon, environment-friendly, green, and ecological industries with high added value. Second, the governing authority should place high priority on intensive vocational training for farmers to encourage the transfer of rural surplus labor, which would yield higher wages from local enterprises and outgoing employment. Third, basic supporting measures, such as the establishment of a minimum income for farmer workers in the trend of an increase in average wage income, and the consummation of the social insurance and re-employment systems, should be considered in order to achieve the aim.

Income from household operations still represents the dominant source of rural income, and its contribution to overall income inequality ranged from 36.40 to $50.39 \%$. This implies that the income from household operations plays the most important role in Aba's rural regional income inequality. Its influence on rural inequality after the earthquake exceeded that before the earthquake. It obviously had a positive effect on reducing the total regional inequality, especially after the earthquake because its concentration decrease effect was greater than the share increase effect during the period. With ecological construction-oriented prohibited and restricted development zones being created in Aba, household operations are affected by the restrictions imposed by relevant polices. Nevertheless, in order to reduce rural income inequality, it would be helpful to decrease the concentration effect by taking certain measures. For local governments, it is necessary to stipulate policies such as rural micro-credit, and agricultural scientific and technical services for rural households, especially poverty-stricken families in minority areas, to develop healthy and sustainable household operation industries and to improve famers' capacity of income increase and self-development. For farmers, it is important to adjust livelihood strategies by engaging in household operations beneficial to the ecological environment construction and accomplishing a shift in farming from traditional agriculture to quality-oriented modern industrial agriculture.

Property income had become the least influential factor as of 2008, when it was affected by the earthquake. It has been slowly recovering and has positively contributed to decreasing the rural income inequality after the earthquake. Because changes in its contribution percentage are small in Aba, governments should help farmers increase property income by the adjustment of land management policies in poverty-stricken areas. Unlike property income, transfer income is becoming a more influential factor, and it positively contributed to decreasing rural income inequality from 2003 to 2011 with peak contribution observed in 2008. Against the macroscopic background of full establishment of a moderately well-off society, but for the long-term tendency to further enhance the transfer support from the central government to the prohibited and restricted development zones, the construction of an ecological environment, the improvement of local famers' livelihood, and the sustainable development of the economy and society in China would not have been possible. Therefore, transfer income should have a role in reducing the rural inequality through innovation and improvement of policies and measures that focus on decreasing its concentration effect. First of all, as a basic means to coordinate fiscal relationships between governments, the fiscal system of transfer payments should be improved in terms of its institution construction at different levels, not only at a national level or 
at a main functional zone level, but also at a river reach level within its upper, middle, and lower reaches of a river basin, aiming to protect local legal rights and interests and to further promote social fairness. Second, categorization and allocation methods, investment direction, and usage of transfer payments should be adjusted to provide better benefits to the prohibited and restricted development zones to relieve the pressure of poverty and sustainable development. Third, for environment construction-oriented prohibited and restricted development zones, investment in the construction of the ecological environment—-such as Grains for Green Projects, the Desertification Control Project, and the State Key Ecological Function Zone Protection Project-should be funded by the central and provincial governments to meet local practical demands as much as possible. Last but not least, for local residents, basic public services—especially education and medical treatment—should be a public investment priority to equalize social public service across different areas.

Author Contributions: Conceptualization, Y.X.; Methodology, Y.X.; Formal Analysis, Y.X. and G.C.; Investigation, Y.X., X.Q., and X.Y.; Data Curation, Y.X. and X.Y.; Writing-Original Draft Preparation, Y.X. and G.C.; Writing-Review \& Editing, Y.X.; Visualization, X.Q.; Supervision, G.C.

Funding: This research was funded by the National Natural Science Foundation of China, under grant number 41671152; and the Key Research Program of the Chinese Academy of Sciences, under grant number KZZD-EW-06-03.

Acknowledgments: We thank expert group of Key Research Program of the Chinese Academy of Sciences (KZZD-EW-06-03) for technical support.

Conflicts of Interest: The authors declare no conflict of interest.

\section{References}

1. Fang, Y.; Fan, J.; Shen, M.; Song, M. Gradient Effect on Farmers' Income in the Mountain Areas and its Implication for Poverty Alleviation Strategies: Empirical Analysis from the Upper Reach of Minjiang River, China. J. Mt. Sci. 2012, 9, 869-878. [CrossRef]

2. Glauben, T.; Herzfeld, T.; Rozelle, S.; Wang, X. Persistent Poverty in Rural China: Where, Why, and How to Escape? World Dev. 2012, 40, 784-795. [CrossRef]

3. Heinemann, E.A. Rural Poverty Report 2011 New Realities, New Challenges: New Opportunities for Tomorrow's Generation; International Fund for Agricultural Development (IFAD): Rome, Italy, 2010.

4. Rodríguez-Pose, A.; Hardy, D. Addressing poverty and inequality in the rural economy from a global perspective. Appl. Geogr. 2015, 61, 11-23. [CrossRef]

5. Lewis, W.A. Economic development with unlimited supplies of labor. Manch. Sch. 1954, 2, 139-191. [CrossRef]

6. Nurkse, R. Problem of Capital Formation: In Underdeveloped Countries, 1st ed.; Eighth Impression; Oxford University Press: New York, NY, USA, 1961; pp. 4-54.

7. Todaro, M.P. A model of labor migration and urban unemployment in less developed countries. Am. Econ. Rev. 1969, 59, 138-148.

8. Schultz, T.W. Investment in Human Capital. Am. Econ. Rev. 1961, 51, 1-17.

9. Jayne, T.S.; Boughton, D.H. What kind of agricultural strategies lead to broad-based growth: Implications for country-led agricultural investment programs? Food Secur. Int. Dev. Policy Synth. 2011, 86, 1-5.

10. Shiva, V. The Violence of the Green Revolution: Third World Agriculture, Ecology and Politics, 1st ed.; Zed Books Ltd.: London, UK, 1992; pp. 11-61, ISBN 978-0862329655.

11. Finger, R.; Benni, N.E. Spatial analysis of income inequality in agriculture. Econ. Bull. 2011, 31, $2138-2150$.

12. Barro, R.J.; Sala-i-Martin, X. Convergence. J. Polit. Econ. 1992, 100, 223-251. [CrossRef]

13. DiCecio, R.; Gascon, C.S. Income convergence in the United States: A tale of migration and urbanization. Ann. Reg. Sci. 2010, 45, 365-377. [CrossRef]

14. Banerjee, B.; Jarmuzek, M. Economic growth and regional disparities in the Slovak Republic. Comp. Econ. Stud. 2010, 52, 379-403. [CrossRef]

15. Arunachalam, R.; Shenoy, A. Poverty traps, convergence, and the dynamics of household income. J. Dev. Econ. 2017, 126, 215-230. [CrossRef]

16. Talukder, D. Agricultural trade liberalization, inequality and poverty in Bangladesh. J. Econ. Dev. Stud. 2014, 2, 47-78.

17. Gao, M.; Yao, Y. Health shocks and farmers' income capabilities. Econ. Res. J. 2005, 40, 15-25. (In Chinese) 
18. Barham, B.; Boucher, S. Migration, remittances, and inequality: Estimating the net effects of migration on income distribution. J. Dev. Econ. 1998, 55, 307-331. [CrossRef]

19. Taylor, J.E. Remittances and inequality reconsidered: Direct, indirect and inter-temporal effects. J. Policy Model. 1992, 14, 187-208. [CrossRef]

20. Militarua, E.; Stanila, L. Income variability in Romania: Decomposing income inequality by household characteristics. Procedia Econ. Financ. 2015, 26, 227-233. [CrossRef]

21. Sok, S. Pro-poor growth development and income inequality: Poverty-related Millennium Development Goal (MDG 1) on banks of the lower Mekong Basin in Cambodia. World Dev. Perspect. 2017, 7-8, 1-8. [CrossRef]

22. Shrestha, S.; Shrestha, U.B.; Bawa, K.S. Contribution of REDD+ payments to the economy of rural households in Nepal. Appl. Geogr. 2017, 88, 151-160. [CrossRef]

23. Severini, S.; Tantari, A. The effect of the EU farm payments policy and its recent reform on farm income inequality. J. Policy Model. 2013, 35, 212-227. [CrossRef]

24. Canagarajah, S.; Newman, C.; Bhattamishra, R. Non-farm income, gender, and inequality: Evidence from rural Ghana and Uganda. Food Policy 2001, 26, 405-420. [CrossRef]

25. Davis, B.; Winters, P.; Carletto, G.; Covarrubias, K.; Quinones, E.; Zezza, A.; Stamoulis, K.; Bonomi, G.; Digiuseppe, S. A cross-country comparison of rural income generating activities. World Dev. 2010, 38, 48-63. [CrossRef]

26. Jiao, X.; Smith-Hall, C.; Theilade, I. Rural household incomes and land grabbing in Cambodia. Land Use Policy 2015, 48, 317-328. [CrossRef]

27. Adams, R. Non-Farm Income, Inequality and Poverty in Rural Egypt and Jordan; Policy Research Working Paper 2572; The World Bank: Washington, DC, USA, 2001.

28. FAO. The State of Food and Agriculture: Rural Non-Farm Income in Developing Countries; Research Working Paper; Food and Agriculture Organization: Rome, Italy, 1998.

29. Ali, A.; Rahut, D.B. Forest-based livelihoods, income, and poverty: Empirical evidence from the Himalayan region of rural Pakistan. J. Rural Stud. 2018, 57, 44-54. [CrossRef]

30. Walelign, S.Z.; Charlery, L.; Smith-Hall, C.; Chhetri, B.B.; Larsen, H.O. Environmental income improves household-level poverty assessments and dynamics. For. Policy Econ. 2016, 71, 23-35. [CrossRef]

31. Angelsen, A.; Jagger, P.; Babigumira, R.; Belcher, B.; Hogarth, N.J.; Bauch, S.; Börner, J.; Smith-Hall, C.; Wunder, S. Environmental income and rural Livelihoods: A global-comparative analysis. World Dev. 2014, 64, S12-S28. [CrossRef]

32. Berman, M. Resource rents, universal basic income, and poverty among Alaska's indigenous peoples. World Dev. 2018, 106, 161-172. [CrossRef]

33. Elbers, C.; Lanjouw, P. Intersectional transfer, growth and inequality in rural Ecuador. World Dev. 2001, 29, 481-496. [CrossRef]

34. Escobal, J. The determinants of nonfarm income diversification in rural Peru. World Dev. 2001, 29, 497-508. [CrossRef]

35. Leones, J.P.; Feldman, S. Nonfarm activity and rural household income: Evidence from Philippine Microdata. Econ. Dev. Cult. Chang. 1998, 46, 789-806. [CrossRef]

36. Janvry, A.D.; Sadoulet, E.; Zhu, N. The Role of Non-Farm Incomes in Reducing Poverty and Inequality in China; CUDARE Working Paper 1001; University of California: Berkeley, CA, USA, 2005.

37. Adams, R. Nonfarm income, inequality and land in rural Egypt. Econ. Dev. Cult. Chang. 2002, 50, $339-363$. [CrossRef]

38. Adams, R. Sources of Income Inequality and Poverty in Rural Pakistan; Research Report 102; International Food Policy Research Institute: Washington, DC, USA, 1995.

39. Lanjouw, P. Rural nonagricultural employment and poverty in Ecuador. Econ. Dev. Cult. Chang. 1999, 48, 91-122. [CrossRef]

40. Lanjouw, P.; Feder, G. Rural Nonfarm Activities and Rural Development: From Experience towards Strategy; Rural Development Strategy Background Paper No. 4; The World Bank: Washington, DC, USA, 2001.

41. Reardon, T.; Taylor, J.E.; Stamoulis, K.; Lanjouw, P.; Balisacan, A. Effects of non-farm employment on rural income inequality in developing countries: An investment perspective. J. Agric. Econ. 2000, 51, 266-288. [CrossRef] 
42. Li, X. Chinese Resident Income Distribution Gap between Regions, 1st ed.; People's Publishing House: Beijing, China, 2010; ISBN 978-7010087634. (In Chinese)

43. Wei, H. Regional Policy in China-Review and Outlook, 1st ed.; Economic management press: Beijing, China, 2011; ISBN 978-7509612248. (In Chinese)

44. Liu, H. Changing regional rural inequality in China 1980-2002. Area 2006, 38, 377-389. [CrossRef]

45. Zhang, P. Rural income inequality and non-agricultural employment in China. Econ. Stud. 1998, 33, 59-66. (In Chinese)

46. Wan, G. Accounting for income inequality in rural China: A regression-based approach. J. Comp. Econ. 2004, 32, 348-363. [CrossRef]

47. Morduch, J.; Sicular, T. Rethinking inequality decomposition, with evidence from rural China. Econ. J. 2002, 112, 93-106. [CrossRef]

48. Benjamin, D.; Brandt, L.; Giles, J. The Evolution of Income Inequality in Rural China; Working Paper No. 654; William Davidson Institute: Ann Arbor, MI, USA, 2004.

49. Wei, H.; Liu, K.; Zhou, M.; Yang, D.; Hu, W. The Development of Region in China-Economic Growth, Changes of the System, Regional Disparity, 1st ed.; Economic management press: Beijing, China, 1997; ISBN 9787801184252. (In Chinese)

50. Fang, H.; Rizzo, J. Income inequality dynamics in rural China from 1991-2006: The role of alternative income sources. Appl. Econ. Lett. 2011, 18, 1307-1310. [CrossRef]

51. Gustafsson, B.; Shi, L. Income inequality within and across counties in rural China 1988 and 1995. J. Dev. Econ. 2002, 69, 179-204. [CrossRef]

52. Chen, $\mathrm{C}$. The changing trend of the gap in the income of farmers in different Provinces of our country and its structural decomposition: 1996-2008. Econ. Surv. 2010, 5, 106-110. (In Chinese)

53. Yang, D. Education and allocative efficiency: Household income growth during rural reforms in China. J. Dev. Econ. 2004, 74, 137-162. [CrossRef]

54. Wan, G.; Zhang, O. Human capital and rural income gap in China: Research methods and empirical analysis. J. Agrotech. Econ. 2006, 5, 13-18. (In Chinese)

55. Wan, G. Economic Development and Income Inequality: Methods and Evidence, 1st ed.; The Joint Publishing Company, Ltd., Shanghai People's Publishing House: Shanghai, China, 2006; ISBN 9787208065833. (In Chinese)

56. Zhong, H. The impact of population aging on income inequality in developing countries: Evidence from rural China. China Econ. Rev. 2011, 22, 98-107. [CrossRef]

57. Zhao, J.; Lu, M. The contribution of Guanxi to income inequality in rural China and a cross-regional comparison: A regression-based decomposition. China Econ. Q. 2009, 9, 363-390. (In Chinese)

58. Ying, B.; Fang, Y.; Xu, Y.; Yan, X.; Hu, H. The heterogeneity of rural household income and its geographical factors in upper reach of Minjiang River. Mt. Res. 2014, 32, 652-661. (In Chinese)

59. Li, J.; Li, S. The impact of the program of farmland conversion for forest land on the income of rural household in Western China: Empirical evidence from the mountain area of the south part of Zhouzhi County, Xi'an City. China Land Sci. 2010, 24, 57-63. (In Chinese)

60. Liu, X.; Xu, J.; Wang, L. Empirical analysis on influences of collective forest tenure reform on farmers' income. J. Beijing For. Univ. (Soc. Sci.) 2011, 10, 69-75. (In Chinese)

61. Zhao, L.; Wang, L. Impact of follow-up industries of land conversion from farmland back to forestland on farmers' income and employment: taking Pingquan County in Hebei Province as an example. J. Beijing For. Univ. (Soc. Sci.) 2011, 10, 76-81. (In Chinese)

62. Luo, C.; Sicular, T. Inequality and Poverty in Rural China; Working Paper No. 201114; University of Western Ontario, Centre for Human Capital and Productivity: London, ON, Canada, 2011.

63. Liu, H. Factor decomposition of rural regional income inequality changes in China. Acta Geogr. Sin. 2008, 63, 799-806. (In Chinese)

64. Wu, J.; Wang, H. Changes trendy and factor decomposition of rural regional income inequality in 2001-2013 from an empirical analysis of the northern and southern parts of Jiangsu province. J. Financ. Superv. 2017, 12, 89-94. (In Chinese)

65. Tang, J.; Deng, C.; Lin, J.; Liu, C.; Wu, Y. The changes and factor decomposition of rural regional income inequality in Hunan Province. Chin. Agric. Sci. Bull. 2011, 27, 472-476. (In Chinese) 
66. He, L.; Luo, X. An empirical analysis of the income gap and its changes of rural residents in ethnic areas-Data from CHNS. J. South-Cent. Univ. Natl. (Humanit. Soc. Sci.) 2014, 34, 109-113. (In Chinese)

67. Sun, H.; Liu, Y. Study on farmers' income difference and its mechanism in Shandong Province. Areal Res. Dev. 2011, 30, 69-77. (In Chinese)

68. Liu, H. Regional inequality measurement: Methods and evaluations. Geogr. Res. 2006, 25, 710-718. (In Chinese)

69. Shorrocks, A.F. Inequality decomposition by factor components. Econometrica 1982, 50, 193-211. [CrossRef]

70. Kimhi, A. Comment: On the interpretation (and misinterpretation) of inequality decompositions by income sources. World Dev. 2011, 39, 1888-1890. [CrossRef]

(C) 2018 by the authors. Licensee MDPI, Basel, Switzerland. This article is an open access article distributed under the terms and conditions of the Creative Commons Attribution (CC BY) license (http://creativecommons.org/licenses/by/4.0/). 